\title{
PROGRESS WITH "SAFE" PASTURE MANAGEMENT IN SOUTH OTAGO
}

\author{
H. J. JAGGER
}

Farm Advisory Officer, MAF, Balclutha

\section{INTRODUCTION}

ONE OF THE reasons for poor lambing performances in South Otago has been the light weight of two-tooth ewes at mating.

From weighings done on a number of farms it appears that to achieve satisfactory two-tooth weights it is a prerequisite that a certain liveweight has to be achieved at the lamb stage, before the first winter. This target is well above the weight being achieved on most farms.

As a means of helping farmers to grow their ewe replacements to the required weights it was decided in 1975 to apply the concepts of integrated grazing management and drenching for the control of internal parasites $\boldsymbol{r}$ as promoted in the booklet Internal Parasites and Animal Production published by the New Zealand Society of Animal Production.

The work at Wallaceville Research Station showed that after weaning, lambs grew faster on "safe" pasture (that is, pasture that has low levels of infective larvae of internal parasites) than they did on contaminated pastures. Safe pastures were shown to increase the response from drenching.

In applying the safe pasture system to a farm situation in South Otago the overall objective was to have the lambs reared all year round on safe pastures or crops.

\section{METHODS}

Table 1 gives the basic data of the three farms at the start of the safe pasture management system, and a control farm. Farms A and $\mathrm{C}$ and the control farm are very typical of farms in the area. Farm B typifies a smaller number of highly stocked all-grass farms.

The principles adopted in producing safe pasture were as follows:

- From lambing to weaning keep all ewes and new season's lambs off the area that will be used for rearing lambs in the weaning to March period. The ewes and lambs should also be kept off the area used for 'lambs the previous autumn because of winter carry over of infection. 
TABLE 1: BASIC DATA OF CONTROL FARM AND THREE SOUTH OTAGO FARMS AT THE START OF THE SAFE PASTURE MANAGEMENT SYSTEM

\begin{tabular}{lcccc}
\hline & \multicolumn{4}{c}{ Control Safe Farm Safe Farm Safe Farm } \\
& Farm & A & B & C \\
\hline Stock wintered, 1975: & & & & \\
Area of farm (ha) & 307 & 336 & 161 & 325 \\
Ewes & 2590 & 2500 & 1800 & 1850 \\
Breed & Romney & Romney & BL $\times$ R & BL $\times$ R \\
Hoggets & 570 & 850 & 500 & 685 \\
Cattle & 69 & 60 & 43 & 161 \\
Grain (ha) & Nil & 26 & 16.6 & Nil \\
Wintering system & Swedes & Swedes & Grass & Swedes \\
$\quad$ for ewes & & & & \\
Wintering system & Swedes & Swedes & Grass & Swedes \\
$\quad$ for hoggets & & & & \\
SU/ha of effective & 10.8 & 10.6 & 16.8 & 10.1 \\
$\quad$ winter grazing & & & & \\
\hline
\end{tabular}

- From weaning to autumn, a period of about 12 weeks, keep all lambs confined to the area of safe pasture prepared for them by immune classes of stock during lambing.

- During the autumn, graze the lambs/hoggets on a part of the farm prepared for them that had no lambs grazing during the previous 12 weeks.

It has been found that planning is best done. in JanuaryFebruary. The process is first to decide on which part of the farm next season's lambs will go after weaning until March, 12 months away. The area of the farm allocated for this purpose will depend on the expected lambing percentage and the number of lambs that might be drafted fat off the mothers.

In South Otago the first month or so after weaning is the most demanding on the safe pastures because very few lambs are drafted off the mothers. A stocking rate of about 35 lambs/ha seems to suit most seasons for this weaning to early February period.

From early February onwards the pressure is not so great because sizable lamb drafts start to go and more safe areas become available from new pastures, hay aftermath, and crops.

Having decided on the area and part of the farm to use after next weaning, the grazing management can be planned back to the present time.

This area automatically becomes the preceding spring area for the ewe hoggets, and the preceding autumn area for these same animals in their lamb stage. 
A quick check will show that this sort of planning satisfies all three principles for producing safe pasture all year round.

This planning process is relatively simple to put on paper or a farm map. It does require a commitment by the farmer to say how he will graze his farm 12 months ahead.

Making it work in practice requires a little more effort.

Grazing control is one of the key factors. From the planning it can be seen that one part of the farm will have lambs or hoggets running on it for 12 months continuously. At most times, but especially at weaning, these pastures should be first class for quality and quantity for lambs. On farms where there are few cattle, or where only a minimum number of ewe hoggets are reared, this can be a problem. When freezing works disputes occur and prevent drafts of ewes and lambs from leaving the property at the planned time, problems again arise. Then there is always the unpredictability of the weather and seasonal growth.

However, this sort of planning started on three farms in South Otago in 1975 and has been carried out with only minor adjustments ever since.

The farmers were left free to give the lambs as many anthelmintic drenches as they thought fit. The only stipulation made was that selenium should be given six-weekly, as is district practice, and drenches be given at weaning and the autumn changeo v e r.

In practice, Farm $\mathrm{A}$ varied the number of anthelmintic drenches given in a year from four to six, Farm B more consistently gave between six and eight, and Farm $\mathrm{C}$ five to six.

\section{RESULTS}

Autumn ewe-lamb liveweights are given in Table 2. These have been adjusted to a common date of May 31, and allowances made for any lines of lambs not shorn during the summer.

All weights shown in 1975 preceded the change in management. Weights from 1976 onwards reflect the new management. Comparison of the figures between the "safe" farms and the control and district averages of "non-safe" farms (either Romney or Border Leicester X Romney) seemed to indicate that by the end of May a safe pasture management system can produce lambs 2.5 to $4.0 \mathrm{~kg}$ heavier than conventional management.

Table 3 shows the two-tooth ewe liveweights. These have been adjusted to a common date of March 31. All weights shown for 1975 preceded the change in management. The 1976 weights are. the result of animals reared for part of their lives under safe 
TABLE 2: AUTUMN EWE LAMB LIVEWEIGHTS (kg) (ADJUSTED TO 31 MAY) OF SAFE PASTURE MANAGEMENT FARMS, CONTROL FARMS, AND DISTRICT AVERAGE

\begin{tabular}{lrrrr}
\hline & 1975 & 1976 & 1977 & 1978 \\
\hline Safe Farm A (Romney) & 33 & 37 & 39 & 37 \\
Stocking rate & 10.6 & 10.4 & 11.6 & 11.9 \\
Control Farm (Romney) & 32 & 29 & 32 & 30 \\
Stocking rate & 10.8 & 10.4 & 10.7 & 10.7 \\
Average of Non-safe Farms (Romney) & 33 & 31 & 34 & 33 \\
$\quad$ No. of farms & 12 & 14 & 11 & 8 \\
Safe Farm B (BLXR) & 33 & 33 & 36 & 36.5 \\
Stocking rate & 16.8 & 15.3 & 15.7 & 14.6 \\
Safe Farm C (BLXR) & 35.5 & 38 & 38 & 38 \\
Stocking rate & 10.1 & 10.5 & 11.0 & 13.1 \\
Average of Non-safe Farms (BLXR) & - & 33.5 & 32.5 & 33 \\
No. of farms & - & 6 & 15 & 14 \\
\cline { 5 - 6 }
\end{tabular}

TABLE 3: TWO-TOOTH EWE LIVEWEIGHTS (kg) (ADJUSTED TO $31 \mathrm{MARCH}$ ) OF SAFE PASTURE MANAGEMENT FARMS, AND DISTRICT AVERAGES OF NON-SAFE FARMS

\begin{tabular}{|c|c|c|c|c|c|c|}
\hline & 1973 & 1974 & 1975 & 1976 & 1977 & 1978 \\
\hline Safe Farm A (Romney) & & & 53 & 57 & 60 & 57 \\
\hline Stocking rate & - & $\rightarrow$ & 10.6 & 10.4 & 11.6 & 11.9 \\
\hline Average of Non-safe Farms (Romneys) & 39 & 47.5 & - & 49.9 & 49.8 & 48.7 \\
\hline No. of farms & 10 & 18 & 1 & 12 & 8 & 5 \\
\hline Safe Farm B (BLXR) & & & 51 & 53 & 60 & 58 \\
\hline Stocking rate & - & - & 16.8 & 15.3 & 15.7 & 14.6 \\
\hline Safe Farm C (BLXR) & & & 49 & 56 & 64 & 55 \\
\hline Stocking rate & $=$ & & 10.1 & 10.5 & 11.0 & 13.1 \\
\hline Average of Non-safe Farms (BLXR) & 44.1 & $52 . \overline{6}$ & 47.6 & - & 51.0 & 51.5 \\
\hline No. of farms & 6 & 9 & 2 & 1 & 5 & 7 \\
\hline
\end{tabular}

Note: Stocking rate $=$ stock units/ha of available winter grazing.

management. The first two-tooths grown for their whole lifetime under the system are the 1977 weighings.

The weights in 1978 were not as good as in 1977, mainly because of an unusually late spring growth which caused pasture control and quality problems. These are accentuated under the safe system. Farm C, in addition, experiened a change of shepherd at this time.

To complete the picture there should be an increase in wool production and lambing percentage. Information on changes in lambing percentages is given in Table 4. The sudden changes on Farms $\mathrm{B}$ and $\mathrm{C}$ can probably be mostly attributed to the change in liveweights. The two-tooths on Farm B were recorded tailing over 
TABLE 4: LAMBING PERCENTAGE OF SAFE FARMS COMPARED WITH COUNTY AVERAGE (Lambs docked to ewes mated)

\begin{tabular}{lrrr}
\hline & 1975 & 1976 & 1977 \\
\hline Bruce and Clutha County* & 100 & 101 & 103 \\
Safe Farm A & 100 & 99 & 100 \\
Safe Farm B & 102 & 104 & 115 \\
Safe Farm C & 102 & 113 & 114 \\
\hline
\end{tabular}

*Lambs docked/ewes wintered (Department of Statistics).

$140 \%$ of lambs in 1977. The no-change on Farm A, up to 1977 , is difficult to explain.

Overall, the gains in two-tooth liveweights appear quite spectacular, especially when the stocking rate on two of the farms was rising at the same time.

\section{DISCUSSION}

From the information to date it appears that safe pasture management can result in at least a $5 \mathrm{~kg}$ liveweight gain in twotooth ewes. It might be reasonable to assume that $3 \mathrm{~kg}$ of this comes from integrated control in the lamb stage and $2 \mathrm{~kg}$ from better feeding in the hogget stage.

One of the features of the planned safe pasture system is that it ensures that in the critical early spring period the ewe hoggets get fed adequately. It could be argued that much of the benefit is coming from better feeding.

It is probably true that from early spring onwards the gains made by hoggets reared on safe farms are all the result of better feeding. It is probably equally true that all the gains made from birth to May can be attributed to integrated control of internal parasites, because over this period safe farms have less choice of quantity and quality of feed than conventional farming.

Over the 3 years some grazing management tips have been leamed. These can be summarized as follows:

1. Plan to have all the lamb/hogget paddocks adjacent to each other to ensure they are kept free of 'ewes and lambs in the spring, and for rotational grazing.

2. The hogget stocking rate in the lambing to weaning period should be light enough to ensure a surplus of pasture growth by December so that lambs are weaned on to adequate goodquality growth. 